\title{
Proposal of the Measures to Increase the Competitiveness of Rail Freight Transport in the EU
}

\author{
Milan Dedík \\ University of Žilina \\ Faculty of Operation and Economics of \\ Transport and Communications \\ Department of Railway Transport \\ Slovak Republic \\ e-mail: milan.dedik@fpedas.uniza.sk
}

\section{Vladimír L’upták \\ Institute of Technology and Business in České Budějovice \\ Faculty of Technology, Department of \\ Transport and Logistics, Czech Republic \\ e-mail: luptak@mail.vstecb.cz}

\author{
Jozef Gašparík \\ University of Žilina \\ Faculty of Operation and Economics of \\ Transport and Communications \\ Department of Railway Transport \\ Slovak Republic \\ e-mail: jozef.gasparik@fpedas.uniza.sk
}

\author{
Zdenka Záhumenská \\ University of Žilina \\ Faculty of Operation and Economics of Trans- \\ port and Communications \\ Department of Railway Transport \\ Slovak Republic \\ e-mail: zdenka.zahumenska@fpedas.uniza.sk
}

DOI 10.17818/NM/2018/4SI.7

UDK 656.23(4)

Original scientific paper

Paper accepted: 28. 8. 2018.

Summary

Ecological and sustainable modes of transport should be the main modes of transport of goods. Promotion of railway freight transport is a key element of the EU policy. It is important to have an appropriate transport infrastructure to ensure sustainable competitive railway transport. It is able to ensure the most flexible mobility of the goods with the most advantageous parameters. This article analyses the current status as well the level of achievement of the objectives set by the European Commission. The article also deals with the established nine corridors for international railway freight transport. The aim is to introduce different measures that should help increase the efficiency and competitiveness of railway freight transport in the European countries under CIM transportation mode. When designing new corridors, it is necessary to analyse and optimize the current railway network. Optimization solutions are used to analyse the network analysis methods. In particular, the critical path method (CPM) and the critical chain method (CCM) are used.

\section{KEY WORDS \\ rail freight corridor international freight transport capacity of corridors railway network}

\section{INTRODUCTION}

The mobility of goods is an essential component of the EU internal market. It is also an essential component for maintaining the competitiveness of the European industry and services, and has a very important impact on the economic growth and the creation of new jobs. Transport is a significant factor of time contribution and forms a very important and irreplaceable location in the logistics chain from the material supplier to the customer. It is important in terms of the speed and reliability of product relocation and is one of the most important elements of the logistics system. However, transport also has a negative impact on the environment and the quality of life of the EU citizens. Therefore, it is very important to prefer the efficient and sustainable modes of transport such as railways and inland water transport. According to the European Environment Agency, the $\mathrm{CO} 2$ emissions from railway transport are 3.5 times lower per tonne-kilometre than emissions from the road transport [1].

It is important to have a good transport infrastructure to ensure sustainable competitive railway transport that can ensure the most flexible mobility of goods with the most advantageous parameters. Therefore, it is necessary to provide a high-quality infrastructure with priority given to the ecological modes of transport, especially water and railway transport. The existence of corridors in railway transport should help increase the number of freight trains on the railways. It means that it will also help increase the transport performance. For this reason, it is necessary to spend the funds efficiently, particularly on the modernization of these routes which connect important economic centres and ports [2].

\section{THE CURRENT SITUATION OF RAILWAY FREIGHT IN THE EU}

The priority of efficient and sustainable modes of railway freight transport has been a fundamental strategic goal of the EU policy since the early 1990s. In 1992, the European Commission set the concept of transferring the balance of the transport of goodes between different modes of transport. The railway sector has been given greater emphasis due to the reduced costs associated with the traffic congestion. By 2050, traffic congestion might increase by up to $50 \%$. Another reason for the greater emphasis is also to reduce the number of victims in traffic accidents. For this reason, the European Commission in 2010 set the objective of maintaining the market share of railway freight transport in the Member States of Central and Eastern Europe atthe level of 35\%. In 2011, this goal particularly 
referred to the transfer of up to $30 \%$ of road freight transport to more than $300 \mathrm{~km}$ on ecological modes of transport by 2030 and more than $50 \%$ by 2050 . All of these objectives have been progressively introduced into the individual EU legislative measures. The purpose of legislative measures is to support security, interoperability, to open up the market and to ensure the non-discriminatory access [1].

In 2014 and 2015, the Court of Auditors performed an audit. The Court of Auditors examined the performance and the planned development of railway freight transport that was established by the European Commission. The results of the audit showed that the performance of railway freight transport in the EU was not satisfactory from the point of view of the transport mode structure and the transport volume. Also, the speed of railway freight trains in the EU is very low (18 $\mathrm{km}$ per hour only on many international routes). As part of the comprehensive assessment, it can be said that railway freight transport in the 21st century is not ablerespond flexibly to the competitive road freight transport. Road transport is the most preferred method by individual carriers [3].

The liberalization of the railway market has not produced the desired effect yet. There is some progress in the Member States but the railway networks of the individual Member States are not fully interoperable. In most cases, the EU funds are directed more towards the road transport than to the railway transport. In particular, the funds spent on the railway transport are not specified for the railway freight transport. The disadvantage of the current status of the railway freight transport is also the pricing of the access to the railway infrastructure - railway freight trains are charged for every kilometre travelled on the infrastructure. Road transport is not like that [4].

\section{THE CURRENT FREIGHT CORRIDORS BY RNE}

The quality of the railway infrastructure has the most significant impact on the sustainability and performance of the railway freight transport. It is extremely important to regularly maintain and modernize the railway infrastructure for the development of the competitiveness of railway freight transport. The poor maintenance of the railway infrastructure and non-effective practices of the transport management often make it more difficult for rail transport to compete with road transport in particular, the infrastructure of which is much more accessible. Maintaining the railway infrastructure to the required quality is particularly important, especially for the railway freight corridors [4].

Just railway freight corridors should improve transport flows across the Member States, with focus on the benefit of the railway freight transport. The selection, organization, management and investment planning of these corridors is provided in the EU regulation No. 913/2010 about the European railway network for the competitive freight transport. The regulation stipulates the establishment of a "one-stop-shop" for each railway freight corridor. The primary objective is to manage the requests for the infrastructure capacity for railway freight trains that pass at one border along the corridor [5].

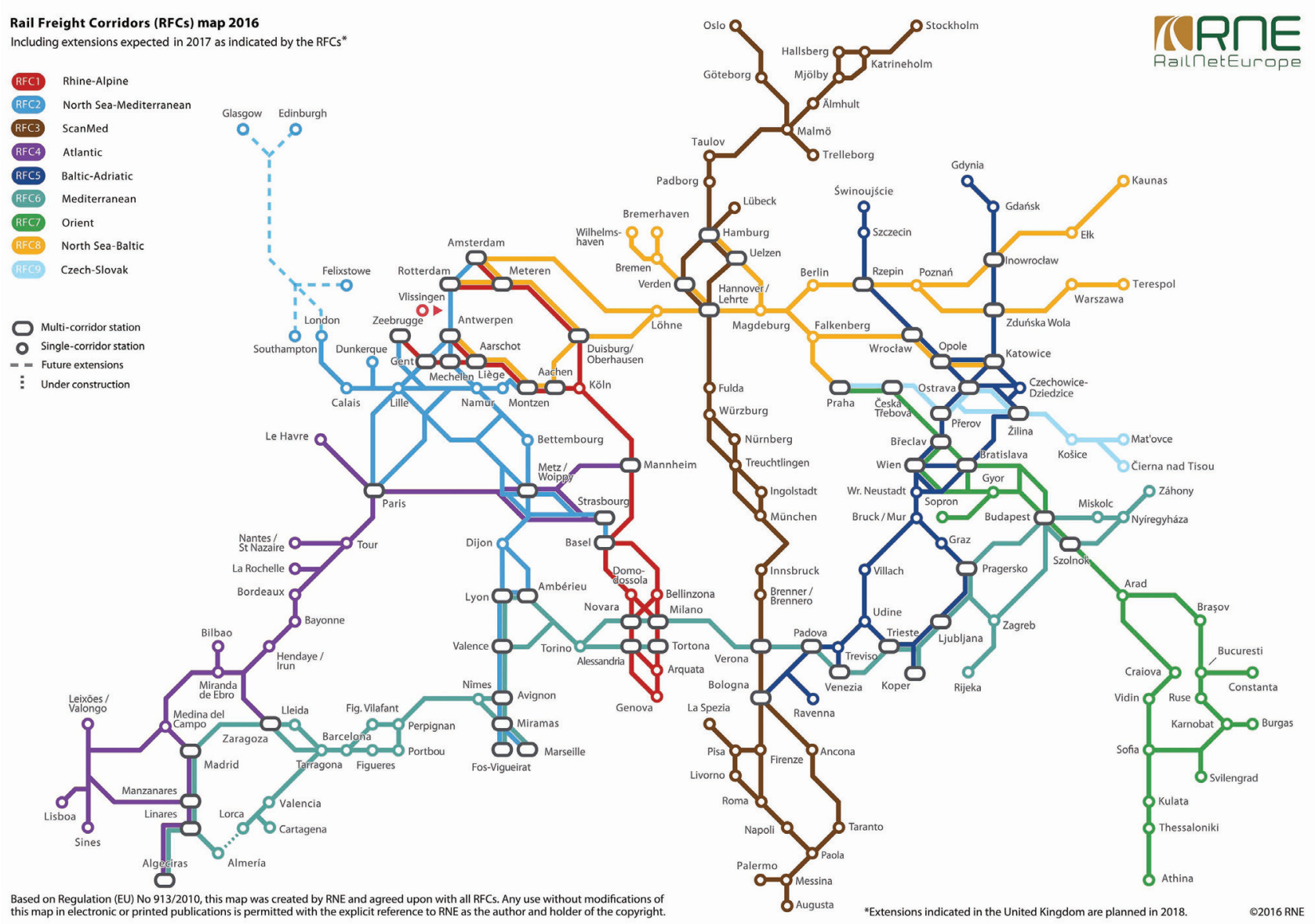

Source: [6]

Figure 1 RNE corridors 
The current main European corridors according to the regulation which use the transportation mode of CIM are shown in Figure 1:

RFC 1: Zeebrugge - Antwerp / Rotterdam - Duisburg [Basel] - Milan - Genoa

RFC 2: Rotterdam - Antwerp - Luxembourg - Metz - Dijon - Lyon / [Basel]

RFC 3: Stockholm - Malmö - Copenhagen - Hamburg Innsbruck - Verona - Palermo

RFC 4: Sines - Lisbon / Leixoes / Sines - Elvas / Algeciras Madrid - Medina delCampo / Bilbao / San Sebastian - Irun Bordeaux - Paris / Le Havre / Metz

RFC 5: Gdynia - Katowice - Ostrava / Zilina - Bratislava / Vienna / Klagenfurt - Udine - Venice / Trieste / / Bologna / Ravenna / Graz - Maribor - Ljubljana - Koper / Trieste

RFC 6: Almeria - Valencia / Madrid - Zaragoza / Barcelona - Marseille - Lyon - Turin - Milan - Verona - Padua / Venice Trieste / Koper - Ljubljana - Budapest - Zahony (HungarianUkrainian border)

RFC 7: Prague - Vienna / Bratislava - Budapest - Vidin - Sofia - Thessaloniki - Athens or Budapest - Bucharest - Constanta

RFC 8: Bremerhaven / Rotterdam / Antwerp - Aachen / Berlin - Warsaw - Terespol (Poland-Belarus border) / Kaunas

RFC 9: Praha - Horni Lidec / Bohumin / Havirov / Zilina Kosice - Cierna nad Tisou / Matovce (Slovak-Ukrainian border)

The current corridors ensure the connection of ports, and larger and smaller cities. The emphasis is placed on the best connectivity of the different parts of Europe. The weaknesses in the railway network were identified, ensuring the network character and connecting the agglomeration with the densest and high-quality infrastructure [6].

\section{PROPOSAL FOR THE SPECIFIC MEASURES TO INCREASE THE PERFORMANCE OF THE RAILWAY FREIGHT TRANSPORT}

It is necessary to design and implement other measures for its development and competitiveness because the current status of the railway freight transport is not optimal. The values of the transport indicators are not satisfactory. The issue of partial implementation of measures in network or carriages is described in scientific papers $[7,8,9,10]$.

\subsection{Proposal of the new European corridors in the CIM mode of transport}

Firstly, there is a need to implement various operationalorganizational and construction-reconstruction measures to increase the capacity of the railway infrastructure. It is important to maintain the maximum competitiveness of the railway freight transport. These measures should be related to corridor lines. The transport of the freight trains should be ensured as quickly as possible on the corridor lines.

For the better and more efficient interconnection of the European countries under CIM transportation regime, we propose the establishment of new corridors for the better interconnection of the existing corridors. New corridors would concentrate more on the railway infrastructure and join the other major European centres. When proposing new corridors, it is essential to analyse and optimize the existing rail network. For this purpose network analysis methods were used. The basic methods of determination of the network analysis include the critical path method of the
CPM and the critical chain CCM method, that both have significant representation in the field of transport planning. When looking for new corridors and new variants for the interconnection of the European railway network, it is also possible to use the transport task. It is the role of the business traveller, and respectively the method of creation of the primary route [11]. There were many studies in this field [12-14].

By using these methods, as well as various empirical and heuristic decision making methods (brainstorming, methods of decision tree, etc.) and also on the basis of expert consultation with the broad professional public, four new corridors were proposed. They are marked with Roman numerals and shown in Figure 2. These are the four corridors:

I. Austrian-German corridor - the corridor leads from the Austrian capital (Vienna) through Linz to Wels, where it branches out. One branch leads through the cross-border station and then to the German cities of Regensburg, Nurnberg (where it crosses corridor number 3), and then the city of Mannheim, where it ends and connects to corridor number 1 . The second branch continues from Wels through Salzburg in Austrian, Rosenheim in Germany, to Munich, Stuttgart and also to Mannheim, where it ends and connects to corridor number 1 .

II. Czech-French corridor - the corridor leads from the capital of the Czech Republic (Prague) to the Austrian cities of Linz (Austria), Salzburg, Innsbruck (from Salzburg to Austria through Bischofshofen in Austria and the second branch through Germany, while in Innsbruck it crosses corridor number 3). Next, two branches lead to Switzerland (one branch through the crossborder station at Feldkirch/Buchs and the other through the cross-border station at Bregenz/St. Margrethen) to Zurich, where it branches out again. One branch leads through the city of Basel (connecting to corridor number 1) to Strasbourg, where it ends and connects to corridors number 2 and 4 . The second branch continues west of Switzerland to the city of Geneve then leads to Lyon, where it ends and connects to corridors number 2 and 6.

III. Polish corridor - the corridor connects the Baltic Sea with the Polish metropolises. It also ensures a more efficient interconnection of the 5th and 8th corridors and leads to the Polish-Ukrainian border. It continues from the ports of Gdynia and Gdansk, through the capital of Warszawa. From there, one branch leads to Psary, where it branches again. It then leads to Katowice and then onto Krakow. The second branch is lead through the towns of Radom, Przeworsk to Przemysl and onto the Polish-Ukrainian border. The last branch connects the cities of Katowice, Krakow, Tarnow, Rzeszow and Przemysl.

IV. Balkan corridor - the corridor connects the important Balkan centres with Budapest, the capital of Hungary. It leads from Hungary to the Serbian towns of Novi Sad, Beograd and Nis, where it branches onto another branch that leads to the Bulgarian capital of Sofia, where it once again connects to corridor number 7. The second branch leads to the Macedonian cities of Skopje and Veles, and onto the Greek port of Thessaloniki, before joining the third branch from Zagreb through Tovarnik to Beograd in Serbia. The fourth branch is directed from Beograd to Podgorica, the capital of Montenegro, with the continuation to the port Bar.

\subsection{Assessment of measures to increase the capacity of corridors}

At present, many important corridors are at full capacity. The requirements for expanding the number of passenger train 


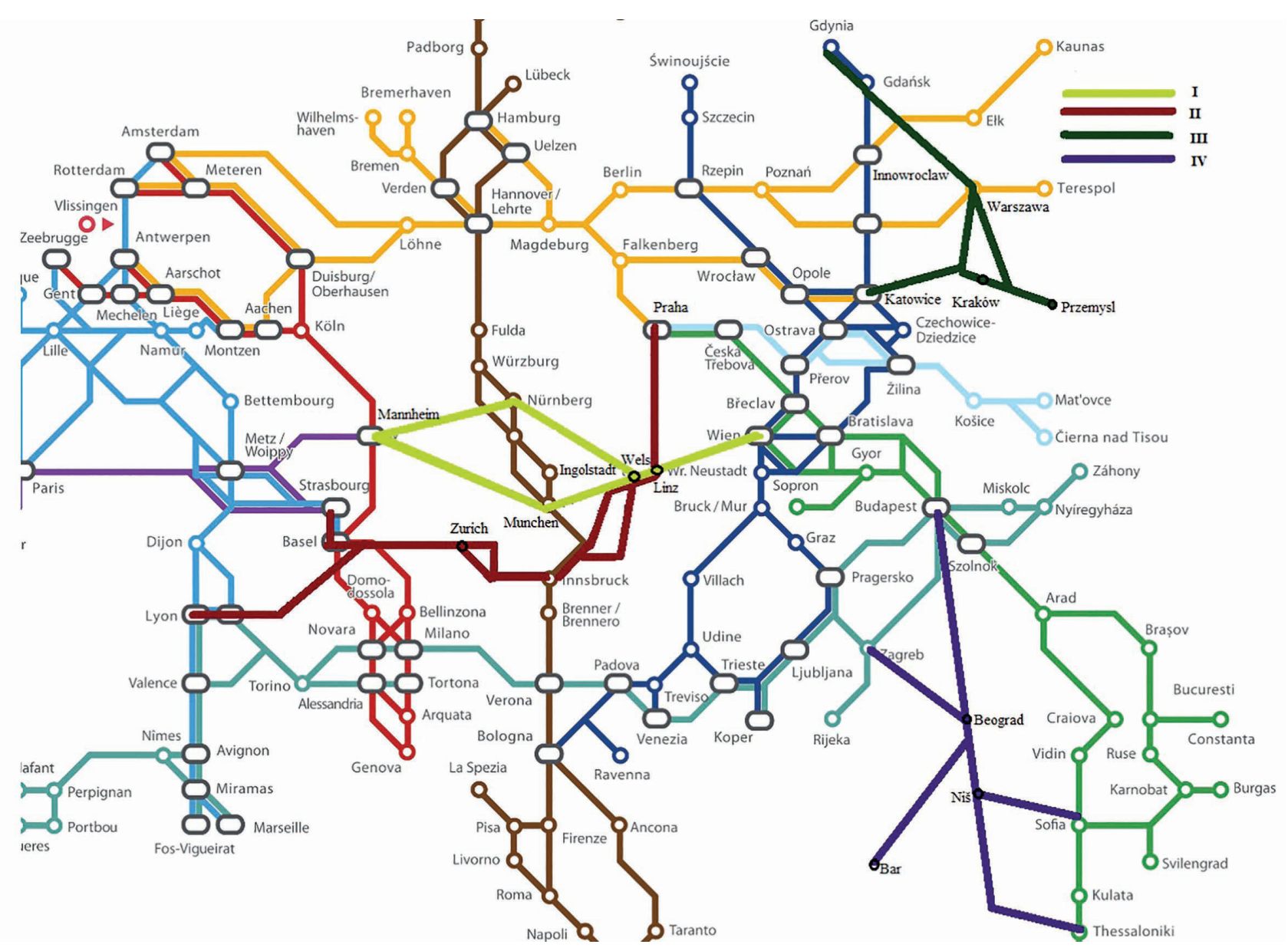

Figure 2 Proposal of new RNE corridors

paths are more increasing, especially on the track sections with high capacity consumption. Therefore, in order to increase the number of freight trains, it is necessary to implement certain measures to increase the track line capacity.

The basic principles of modernization particularly of the important corridors consist of increasing the critical running speed and building platforms at stations not on the main tracks (but at a side track). Creating modern stations and track safety devices, along with adapting the European Train Control System (ETCS) are very important. As track safety devices the automatic block signals are propsed instead of automatic blocks. Other modern principles include the cancelling of some stations and the complex introduction of simplified overtaking stations with a single crossover in the boundary interstationary. It is necessary to divide them into more than two block sections which are generally unilaterally arranged [16].

All these measures have a significant impact on the organization of rail transport and the track line capacity. In its general analysis and assessment, a number of different approaches emerged from the historical perspective of the different practices applied by various infrastructure managers. While a uniform methodology for assessing the railway infrastructure capacity is not used, the analytical or graphical methodologies, or combinations thereof, are applied. [16] In recent years, the simulation procedures have come to the fore. The railway infrastructure capacity is more affected by the station and track safety devices than the station and track operational intervals.
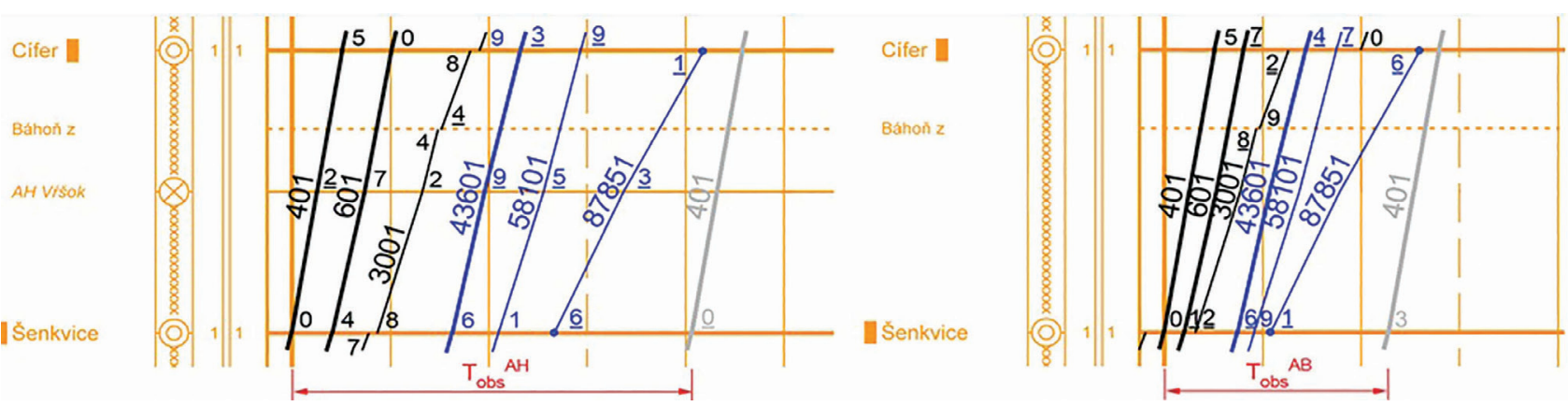

a) trains sequence under automatic block signal $A B S$

b) trains sequence under automatic block $A B$

Source: [16]

Figure $3 \mathrm{~A}$ comparison of the occupancy time according to the used of line safety device on the $5^{\text {th }}$ RFC corridor (Slovakia) 
From the point of view of track capacity on a one-way track (usually double-track), occupation time is done as headway. Increasing the number of block sections leads to the reduction of headway, but an increase of capacity is slower.

A comparison of the advantages of the automatic block (AB) and automatic block signal (ABS) has been done on a current railway section in Slovakia. The evaluated track section was modernized and it belongs to the 5th corridor. There was no AB on this track section before the reconstruction. The BratislavaTrnava track line section was overextended. There is a boundary interstationary section on Šenkvice-Cífer. It is the longest track section with a length of 11.8 kilometres and a maximum track line speed of $160 \mathrm{~km}$.h-1. The track section is divided with an ABS signal device into a two block section (with a length of 6 kilometres). In this track section, the total occupancy time is 40.5 minutes with a selected sequence of six trains for the automatic block signal (see figure 3a). In terms of implementation of an automatic block, an occupancy time of just 23 minutes (see the comparison in figure $3 \mathrm{~b}$ ) is also under consideration. The automatic block is analysed with 10 block sections and with an average length of 1200 metres. This comparison illustrates the advantages of an automatic block compared to an automatic block signal of particular trains in the train traffic diagram [16].

It is clear from the above data that an increase in the number of freight trains can be considered, in particular on lines with such track-side safety devices where the capacity is as high as possible. Therefore, it is most advantageous to build an automatic block on the corridor tracks that have a capacity problem in order to shorten the headway time. A series of automatic block signals in the interstationary section can be proposed as an equivalent to the automatic block.

\subsection{Assessment of other measures}

In order to ensure a competitive rail freight transport conditions in the EU, it is also necessary to make a number of further recommendations. These are recommended by the Court of Auditors and are focused on two main issues.

At first, it is necessary to improve the strategic and regulatory framework which defines the basic conditions for the transport of goods by rail. For this purpose, the Commission should be in cooperation with the EU Member States. They should focus primarily on the lack of capacity to liberalize the rail freight market and also on the procedures and principles of the traffic management. For example, the main principles of the traffic management should take into account the timetable for the allocation of routes and the number and quality of the routes offered. It is also very important to effectively address the issue of interoperability, administrative-technical constraints, priority in the field of vehicle harmonization and approval, and the issue of safety certificates to railway undertakings. It is also a matter of optimization of the transparency of the performance of the rail freight sector and the establishment of fair competition between different modes of transport. Traders do not decide on the basis of EU priorities but on the basis of business criteria. Therefore, if it does not change the above for the better, it will be far more advantageous for them to focus on road transport in this case [17-19].

Secondly, the Court points to a more efficient use of EU funds in focusing on the rail freight sector. To this end, the Commission and the Member States should provide for improvements, preferably in the areas of a coherent approach between strategic policy objectives and the allocation of funds with a major focus on the rail freight corridor. Last but not least, the selection, planning and management of projects are very important. Quantitative objectives for freight transport should also be included in project matters, including the volume of transported goods, the number of freight trains, or the average service speed of freight trains [1], [20], [21].

\section{CONCLUSION}

The article focuses on the current problems of railway freight transport in EU corridors and offers various proposals for solutions. Based on the current state of knowledge, four new freight corridors have been proposed based on the existing scientific methods, which will enable the more efficient interconnection and concentration of the existing rail transport network. The other proposed measure concerns the increase of the railway infrastructure capacity, where emphasis is placed on the preference of trackside signalling equipment with the possibility of the highest permissible railway performance. The last group of proposals is based, in particular, on the recommendations of the Court of Auditors, which, on the basis of an analysis of the current situation, creates a set of additional measures, particularly in the areas of organization, operation or transport economy.

Implementation of the proposed measures should be a tool for competitive rail freight. At the same time, it will support the European Commission's ambitious long-term goals for the 2030s and 2050s. The aim is to increase transport performance not only within rail freight itself, but also in intermodal transport where rail transport is irreplaceable. It is also very important to point out that the effective introduction of favourable measures for the development of rail freight should be of a long-term nature, with the vision of building a concept for the revitalization of rail freight which has stagnated in recent years.

\section{Acknowledgement}

The paper is supported by the VEGA Agency under Project 1/0095/16 "Assessment of the Quality of Connections on the Transport Network as a Tool to Enhance the Competitiveness of Public Passenger Transport System", which is carried out at the Faculty of Operations and Economics of Transport and Communication, University of Žilina.

\section{REFERENCES}

[1] European court auditors. Railway freight transport in the EU: still not on the right track. Luxembourg, 2016. ISBN 978-92-872-4601-1. DOI: 10.2865/638450

[2] Stopka, O., Černá, L., Zitrický, V. Methodology for measuring the customer satisfaction with the logistics services. Naše more, 2016, Vol. 63, No. 3, pp. 189-194. ISSN 0469-6255

[3] Kudláč, Š., Majerčák, J., Majerčák, P. Comparison of different variants of logistics chain with the use of air transport using the software application. In: International conference on Air transport - INAIR 2017, Transportation Research Procedia, 2017, Vol. 28, pp. 45-50. ISSN 2352-1457.

[4] Záhumenská, Z., Gašparík, J. Supporting the connection the logistics centers to rail network. In: Transcom 2017, Proceedings of the 12th international scientific conference, 2017, Vol. 192, pp. 976-981. ISSN 18777058. Retrieved from: http://www.sciencedirect.com/science/article/pii/ S1877705817327157.

[5] Dedík, M., Gašparík, J., Záhumenská, Z. Quality assessment in the logistics of rail passenger transport. In: Logi 2017, 18th International Scientific Conference Proceedings, 2017, Vol. 134. https://doi.org/10.1051/matecconf/201713400009

[6] Rail Freight Corridors (RFCs) - General Information. RNE, 2017. Retrieved from: http://www.rne.eu/rail-freight-corridors/rail-freight-corridors-generalinformation/. 
[7] Voropai, V. Development of a design-experimental methodology for the prediction of reliable exploitation of freight railway cars. Tranport Problems, 2017, Vol. 12, No. 3, pp. 21-34, DOI:10.20858/tp.2017.12.3.2

[8] Wojtowicz, D., Wolański, M., Widla-Domaradzki. The use of conjoint method for assessing the relevance of railway investments. Transport Problems, 2015, vol. 10, No. 1, pp. 121-135, https://doi.org/10.21307/tp-2015-013

[9] Palúch, S., Peško, Š., Majer, T., Černý, J. Transportation network reduction. Transport Problems. 2015. Vol. 10, No. 2, pages 69-74. DOI: 10.20858/ tp.2015.10.2.7.

[10] Bisták, M., Brumerčík, F., Lukáč, M. Weighing systems in traffic. Scientific Journal of Silesian University of Technology. Series Transport. 2017, 97, pp. 5-15. ISSN: 0209-3324. https://doi.org/10.20858/sjsutst.2017.97.1

[11] Enviroportal - Information portal of MoE of Slovak republic. Retrieved from: https://www.enviroportal.sk/indicator/detail?id=763\&print=yes.

[12] Roso, V., Brnjac, N., Abramović, B. Inland Intermodal Terminals Location Criteria Evaluation: The Case of Croatia. Transportation journal, 2015, Vol. 54, No. 4, pp. 496-515. https://doi.org/10.5325/transportationj.54.4.0496

[13] Ficzere, P., Ultmann, Z., Török, A. Time-space analysis of Transport System using different mapping methods. Transport, 2014, Vol. 29, No. 3, pp. 278-284. https://doi.org/10.3846/16484142.2014.916747

[14] Zefreh, M. M., Meszaros, F., Junevicius, R. et al. Economic investigation of a public transport support policy: A case study at Budapest. Promet-Traffic \& Transportation: scientific journal on traffic and transportation research, 2017, Vol. 29, No. 1, pp. 77-84. https://doi.org/10.7307/ptt.v29i1.2072

[15] Gašparík, J., Abramović, B., Halás, M. New graphical approach to railway infrastructure capacity analysis. Promet - Traffic\& Transportation: scientific journal on traffic and transportation research, 2015, Vol. 27, No. 4, pp. 283290. https://doi.org/10.7307/ptt.v27i4.1701

[16] Gašparík, J., Zitrický, V., L'upták, V. The impact of the modernization of ŽSR railway corridors on their capacity. In: Horizons of railway transport 2015, conference proceeding 2015, pp. 86-93. ISBN 978-80-554-1097-5.

[17] Chovancová, M., Klapita, V. Draft model for optimization of the intermodal transport chains by applying the network analysis. In: Transport means 2016: proceedings of the 20th international scientific conference, Juodkrante, Lithuania, 2016, pp. 112-116. ISSN 1822-296X.

[18] Stopka, O., Chovancová, M., Kampf, R. Proposal for streamlining the railway infrastructure capacity on the specific track section in the context of establishing an integrated transport system. In: MATEC Web of Conferences, Vol. 134, Article number 00055, 18th International Scientific Conference, LOG 2017, Ceske Budejovice; Czech Republic, 19 October 2017, Code 131750. https://doi.org/10.1051/matecconf/201713400055

[19] Bartuška, L., Biba, V., Kampf, R. Modeling of daily traffic volumes on urban roads, Proceedings of the third international conference on traffic and transport engineering (ICTTE), 2016, pp. 900-904. ISBN 978-86-916153-3-8.

[20] Klapita, V. Modeling of intermodal transport chains in selected transport relations. Railway transport and logistic, scientific and technical on-line journal. University of Žilina, Žilina, 2012, Vol. 8, No. 2, pp. 39-46. ISSN 13367943.

[21] Gorlewski, B. Travel cost reduction as a factor of economic appraisal of highspeed rail project. Logi - Scientific Journal on Transport and Logistics, 2011 Vol. 2, No. 1, pp. 16-26. ISSN 1804-3216. 